\title{
THEOLOGICAL EDUCATION IN SOUTH AFRICA AND THE EPISTEMOLOGICAL DIVIDE: IN SEARCH OF THE AFRICAN HABITUS
}

\author{
AO Balcomb \\ School of Religion and Theology \\ University of Kwazulu Natal
}

\begin{abstract}
The ethos of the academy in South Africa, as is the case in the West in general, has been shaped profoundly by the Enlightenment. Theological and religious studies in the secular academy have had to conform to this ethos. This has led to the anomalous situation of African students of theology being alienated from their faith at university level despite the fact that the sub-continent appears to be overwhelmingly Christian in its ethos. Theology departments need to take more seriously the epistemological divide between students of theology coming from an African background that has had little or no exposure to the critical approach that emerged within the history of the academy in the West. This does not mean that the critical approach must be abandoned but rather that it should be applied more rigorously to the secular world view of the university itself and recognition given of alternative world views that shape the African habitus. Such forms of contextualisation mean, amongst other things, that a more sympathetic articulation of the faith in African terms needs to be emphasised, the social sciences should not take the place of theology; an alternative, non-secular account of human rights needs to be found, and development discourse needs to take seriously Indigenous Knowledge Systems.
\end{abstract}

Key Words: $\quad$ World View; Emic vs Etic; Secularisation; Faith Seeking Understanding; Contextualisation

Scholars of African Christianity appear to unanimously agree that [as Lamin Sanneh puts it] "Africa has become, or is becoming, a Christian continent in cultural as well as numerical terms, while on the small scale the West has become, or is rapidly becoming, a post-Christian society". ${ }^{1}$

Sanneh's assertion of the 'unanimous' agreement amongst scholars of African Christianity that the continent of Africa can now be described as Christian in the cultural as well as numerical sense, although possibly overstated, ${ }^{2}$ suggests that Christianity south of the Sahara and African identity are now indissolubly linked. This was once again recently highlighted in the South African situation with the appointment of Justice Mogoeng Mogoeng as Chief Justice of the supreme court. Mogoeng is a member of a conservative Pentecostal church and made no secret of his belief that God was calling him to the job. But

\footnotetext{
1 James Kombo, "The Past and Presence of Christian Theology in African Universities" in Handbook of Theological Education in Africa, I Phiri \& D Werner (eds.). Pietermaritzburg: Cluster Publications, 2013:100-107;104.

2 Such an assertion, for example, can surely only apply to Sub-Saharan Africa because North Africa is dominated by Islam.
} 
it was a throw-away phrase of a fellow-judge that highlighted the extent to which the Christian religion has penetrated South African society. "He is a Christian," said Judge Leeuw, "like all of us". 3 In this essay I will give a brief overview of the extent to which Christianity has apparently taken hold of the African imagination and then discuss the challenges that this presents for theological education in South Africa.

\section{Christianity and the African Habitus}

That sub-Saharan Africa is now overwhelmingly Christian is common knowledge. The latest evidence of this comes out of the recent conference, held in Edinburgh, which was used as an opportunity to survey the church's mission over the past one hundred years. The success of this mission, especially in Africa, has been nothing short of spectacular. It has, in the words of Kenneth Ross, one of the editors of the Atlas of Global Christianity that came out of the conference, 'surpassed even the most sanguine expectations of 1910' and could not have been 'foreseen by any of the Edinburgh delegates' of that year. ${ }^{4}$ The Atlas gives extraordinary visual impact to the reality of the shift of the centre of gravity of the Christian faith from the North to the South. In almost all sub-Saharan African countries, the growth of Christianity has outpaced population growth. In 1910 Africa was less than $10 \%$ Christian, in 2010 it was almost 50\% Christian with sub-Saharan Africa at least $70 \%$ Christian. ${ }^{5}$ Another statistic puts the population of Christians in Africa in 1900 at 8.7 million, projected to be 633 million in 2025 at the present rate of growth. ${ }^{6}$ Philip Jenkins argues against the idea that Africa was ever 'off the map' when it came to the Christian religion and maintains that, contrary to other religions in other parts of the world, African Christianity is a grassroots movement that is taking place from 'the bottom up', significantly among the youth because of its high mobility across society (2002:43).

The reasons for such growth are many and varied. Clearly a major factor is the association between the Christian mission and Western notions of education and development. To survive in the modern world these notions have to be appropriated; they were originally brought to Africa by the Christian mission; mutatis mutandis, therefore, Christianity was embraced because a Christian education was necessary. Such a process, however, does not explain the extent to which Christianity as a religion has been embraced. And whereas the link between modern education and the Christian religion has long since been severed in the West this is not the case in Africa. Thus the epistemological dimension has become an important explanation. Christianity was, simply, the "best means of explaining the world around them" (Jenkins 2002:44). Arguably, however, there is something even deeper than this - something, as Chinua Achebe puts it, that was, "felt in the marrow" of Africans. This is depicted brilliantly in one of the characters created by Achebe in Things Fall Apart. "It was not the mad logic of the Trinity that captivated him", writes Achebe:

it was the poetry of the new religion, something felt in the marrow .... He felt relief within as the hymn poured into his parched soul. The words of the hymn were like the

Sibusiso Ngalwa "Judging the Judge" in Sunday Times Review, August 21, 2011. Judge Leeuw was trying to allay the fears of many critics of the Mogoeng appointment that he would allow his conservative faith to influence his deliberations as Chief Justice.

4 David Kerr \& Kenneth Ross, "Edinburgh 2010 - Mission then and now", in Atlas of Global Christianity, Todd Johnson (ed.). Edinburgh: Edinburgh University Press, 2010:314.

Phiri and Werner 2013:xxvii.

6 Kombo 2013:105. 
drops of frozen rain melting on the dry palate of the panting earth. Nwoye's callow mind was greatly puzzled (Achebe 1959:137).

"For the fictional Nwoye", says Jenkins, "and for millions of his real life counterparts, Christianity was accepted because it spoke to them, because they found it to be true". 7

Such a description of the effect of the Christian religion on Africans suggests that for many Africans, inhabitants of South Africa included, Christianity has been adopted into the habitus. This notion, first used by Aristotle and subsequently appropriated by Bourdieu and others, describes the process whereby a particular set of beliefs has become insinuated into the cultural identity of a people and part of the unconscious set of dispositions and attitudes that incline them to believe, interpret, construct meaning, act and react in a certain way, thus constituting part of their cultural capital. It is this notion of theology incubated within the African habitus that I am arguing should inform an agenda for theological education in Southern Africa because it reaches to the heart of how Christianity has been received, translated, negotiated, transacted and transformed amongst ordinary South Africans ever since the advent of the Christian mission. It is not only what the gospel has done to Africans that needs to be understood but what Africans have done to the gospel.

What challenges does this pose for theological education in institutions of higher learning in South Africa? I will take as my point of reference my own institution, that is the School of Religion, Philosophy, and Classics, at the University of KwaZulu-Natal (UKZN), but am of the opinion that while the details may differ in other institutions the basic issues are the same. I will not base my critique on formal empirical research but on my experience of teaching theology for some ten years at UKZN during which time I also served as Southern African co-ordinator for the African Theological Fellowship (ATF). ${ }^{8}$

\section{Theological Education in South Africa and the Epistemological Divide}

John Mbiti tells the story of a theological graduate returning home to Africa with a PhD from a Western institution. He arrived amidst high expectations of what his great accomplishment and newfound wisdom would do for his community. During the homecoming festivities there is a shriek from his older sister who falls to the ground in a fit. The chief diagnoses immediately that she is being troubled by the spirit of her great aunt and the people expect their returning hero to be able to deal with the problem. Instead he calls for her to be taken to hospital but it is quickly pointed out to him that this is a case that hospitals cannot cure. He turns to his books of Western theology and discovers that Bultmann has demythologised the issue of spirit possession. To the acute despair and embarrassment of everyone, most of all himself, he is utterly helpless in the situation. Mbiti ends his story with the following words: "Fantasy? No, for these are the realities of our time". 9

The story is hypothetical but the message is clear - that is that a Western theological education, far from equipping African graduates for ministry back home, alienates them

Philip Jenkins, The Next Christendom - the coming of Global Christianity. New York: Oxford University Press, 2002:44.

8 The ATF is a network of African scholars, broadly evangelical in persuasion, across the African continent whose purpose is to promote theological education and research on the sub-continent at an advanced level.

9 Kwame Bediako, Christianity in Africa: The Renewal of a Non-Western Religion. Edinburgh: Edinburgh University Press, 1995:156. 
from their faith, their context, and their people. Is Mbiti's claim that "these are the realities of our time" true for the South African context in the $21^{\text {st }}$ century? My contention is that in principle it is, though there are assumptions implicit in the story that cannot be made today. These are the following:

- Firstly there is the assumption that the context was rural - the reference to the chief and the fact that the nearest hospital was many miles away is evidence of this. Clearly this assumption cannot be made today. While there might be some cases where the home situation is rural, it is more than likely that today it will be urban. And with the extraordinary growth of Pentecostalism in the urban centres and their hunger for a theological education there is a strong possibility that the returning graduate will be a Pentecostal. There is also an increasing possibility that the graduate will be a member of an African Independent Church, whose knock on the door of the academy is becoming increasingly louder.

- Secondly there is the assumption that the returning graduate will be male. This assumption can no longer be made as an increasing number of female theological candidates are entering the field.

- Thirdly the assumption is that the student studied abroad, that is at an overseas institution. This assumption cannot be made today for South African students of theology, though, as I will argue later, the intellectual influences on the secular academies that dominate the landscape of higher learning are the same in this country as they are for those in Europe and North America.

- Fourthly the assumption is that the theology learned in the academy was dominated by the great liberal European and North American theologians of the nineteenth century. This assumption cannot be made in South Africa today as it is more likely that the influences will be various forms of Contextual and Liberation theologies, though in some cases Reformed or Lutheran.

What, then, is left in Mbiti's story that is relevant today?

- Firstly the strong emphasis on the desirability of a higher education.

- Secondly the assumption that such an education, whether it be in theology or not, will be 'Christian' in the sense that it resonates with the notion of habitus described above.

- Thirdly that such an education should be able to meet the needs of ordinary people living with a non-secular world view that continues to take seriously the possibility of unseen forces that impact on their lives.

- Fourthly that the reality on the ground will be a theological education that will not be able to meet these needs.

Underlying all these assumptions is the epistemological divide that exists between the academy and society. I would like to unpack these assumptions a little further.

Education in Africa, South Africa included, by definition implies a Western, Christian, education. There are those African intellectuals who resist this thesis because of its association with colonialism. ${ }^{10}$ But it is impossible even for them to escape the historical fact that Western education came initially with the Christian mission. Indeed, in most cases the education of their parents, if not their own, took place in mission schools, as did the

10 For example Okot p'Bitek. Wole Soyinka, Ngugi wa Thionga, Chinweizu, amongst others. 
education of all the first crop of African Nationalist leaders throughout the sub-continent, including all the early leaders of the African National Congress. This point needs to be emphasised firstly because it has played a crucial role in the inculcation of Christianity into the South African national habitus and secondly because it is at serious odds with the Western scenario. While higher education in the West has long since cut any umbilical cord with Christianity that it might originally have had, in the African imaginary the relationship between Christianity, education, and development is embedded in the national psyche because of its history. ${ }^{11}$ This is in stark contrast to the situation in the West where the church has lost its role as leader in society and where religion is no longer associated with personal advancement. Indeed quite to the contrary - a PhD in theology in the secular West would get one practically nowhere. The irony of seeking a theological education and thus advancing oneself in life in places where such advances have taken place in the wake of the demise of religion would not be that significant if it were not for the fact that the Western academy is itself a bastion of the secular values of the society around it. We have, therefore, a situation where the relationship between the Christian faith and intellectual advancement are indissolubly linked, but there is a profound hiatus in such a relationship in the institutions that are ostensibly responsible for such advancement. Such a contradiction puts extraordinary strain on African students of theology and its psychological and pastoral implications for them are profound. In my own institution this led to a variety of coping mechanisms amongst students who had a profound psychological need to separate their Christian faith from their academic studies in order, simply, to preserve the former.

I have specifically retained the assumption about the world view of the home community because there is no indication that in the South African situation - as is also the case in the rest of the continent - modernity has led to a demise of the widespread belief in a spirit world that is co-terminus with the material world. On the contrary there is ample evidence to show that in the South African situation such a world view continues unabated (see, for example, Ashforth 2005, Ellis \& Ter Haar 2007).

The question needs to be asked what exactly constitutes the ethos of the academy that leads to the epistemological crisis that is the lot of many African students of theology. ${ }^{12}$

\section{Understanding the Epistemological Crisis - the Academy and the Enlightenment}

To understand the epistemological divide between African students of theology and their home communities one has to understand the epistemological ethos of the university which is profoundly shaped by the Enlightenment. The Enlightenment did three things: First, it established the centrality of the 'organised habit of criticism' and the 'political demand for the right to question everything'. ${ }^{13}$ Credulity, the penchant to believe easily, was the pet aversion of the scholars of the eighteenth-century Enlightenment and it has become a tradition in the modern academy to lay siege to it. Second, it carried forward what had

\footnotetext{
11 For a detailed history of the role of the Christian mission in the shaping of African Nationalism in South Africa see Elphick 2012.

12 I am using the generic term "African" here even though I have in mind the South African situation. Many, if not most, of the students of theology in my institution are black non-South Africans.

13 Peter Gay, The Enlightenment, An Interpretation - the Rise of Modern Paganism. London: Weidenfeld \& Nicolson, 1969:141.
} 
already begun in the previous century concerning the disenchantment of the universe. It had to be rid of what Charles Darwin called 'caprice', in other words of any magic, or supernatural agency of and in itself in the world. In other words, the world had to be inanimate, objectified, if it was to be understood correctly. Third, the Enlightenment elicited a passionate concern for human rights. All three of these things have constituted the core of the intellectual legacy of the West ever since the eighteenth century and all three have become potentially lethal for the study of religion and theology within the secular university. ${ }^{14}$ To question them is to question the meaning of the existence of the modern academy. Historically theology was the first victim of the secular purge that needed to take place in the university in order to rid it of the influence of the church, which had lost its intellectual credibility through a series of blunders where it set itself up against scientific discoveries. Early examples of this were the fights with Copernicus and Galileo and, later, with the evolutionary hypothesis and the Scopes trial. These battles have long since been forgotten, but their secularising influence has become embedded in the ethos of the Western academy. For theology to regain any credibility in the university it had to show itself to be equally rigorous in respect of all three of the essential characteristics I have mentioned above. In other words, it had to question the faith, reject all non-material causal influences in the world, and be committed to human rights. It is considered immoral and foolish to ignore them and preposterous to reject them. It is therefore apparently the moral and intellectual duty of a university to bring its students to conform to them. Questioning the faith amidst such an ethos takes place within the paradigm of God's absence rather than presence, ${ }^{15}$ rejection of non-material influences leads to the pre-eminence of the social sciences as a methodological tool in order to explain why it is that people believe in a spiritual universe in the first place, and the issue of human rights is premised on the idea that faith in God, far from being friendly to the idea, is more often than not antipathetic towards it. ${ }^{16}$

I have deliberately characterised the Enlightenment tradition in these terms in order to place it in stark contrast to a paradigm that has had no such influence simply because it has not had the same history. In such a paradigm the concern is to strengthen and apply faith rather than interrogate it, assume that non-material causation in the universe is the norm namely God and the Holy Spirit as well as other spiritual agencies - and put the notion of the Word of God before the notion of human rights. ${ }^{17}$ For the Enlightenment paradigm to begin to make any sense in such a context, the entire plausibility structure of the African

14 I use the word "potentially" here advisedly. It is not that the Enlightenment destroyed the possibility of the study of Religion and Theology in the secular university, but that it made emic study of these disciplines very difficult. If the Anselmian definition of theology as "faith seeking understanding" is correct (as it was so deemed up until the Enlightenment) then after the Enlightenment faith itself became problematic. For a full analysis of this particular problematic in the wake of secularism see Taylor 2007.

15 I have argued elsewhere ("The Great Comeback of God(s) - theological challenges and opportunities in a post-secular age" (Missionalia, 2010, vol 38, no. 3, November, pp. 414-430.) that modern European theologians did theology without having God, but they did have the void that was left by God and they thought and spoke about this void with extraordinary eloquence.

16 The University of KwaZulu-Natal is a classic case of the impact of the Enlightenment tradition on religious and theological discourse in the modern academy. The original Department of Theology became the School of Ethics. The subsequent School of Theology, which was funded by the Lutheran World Federation, has now become the School of Religion, Philosophy, and Classics and lost all pretence of being confessionally based. 
world-view would need to be dismantled. ${ }^{18}$ It is my contention that one of the biggest challenges facing theological education in South Africa is precisely the epistemological hiatus that exists between African students of theology and the Western liberal academy stemming from the scenario that I have outlined above.

\section{African Theology in the European Academy - Unpacking some of the Challenges ${ }^{19}$}

African theologians from the beginning have been preoccupied with two overriding concerns - reception and enculturation. The first is to do with the overwhelming acceptance of the Christian gospel as described above, the second is to do with the rejection of the Western forms within which it has come. I have characterised these two dynamics as what the gospel has done to Africans and what Africans have done to the gospel. From Bolaji Idowu's recommendation of a separate indigenous church at one end of the spectrum (Idowu 1973) to Byang Kato's attempt to preserve a purified gospel at the other (Kato:1975), African theologians have attempted to contextualise the Christian gospel in African terms.

There is probably no more succinct and comprehensive an overview of African Theologies than Maluleke's "Half a Century of Christian Theologies" (Maluleke 1997). Maluleke's main contention is that we should rather talk of African Christianities in the plural rather than in the singular because of the proliferation of diverse forms of the faith. He identifies five kinds of 'emerging' theologies in the sub-continent: those of the African Independent Churches, Evangelical/Pentecostal theology, African Womanist/Feminist theology (Mercy Odoyuye being a key figure), Translation theology (associated with the works of Sanneh and Bediako), and the theology of Reconstruction (associated with the Kenyan theologian Jesse Mugambi). Conspicuous by its absence in this typology is Liberation Theology. Although elsewhere in his paper he argues against the distinction between theologies of liberation and enculturation, ${ }^{20}$ the exclusion of a genre of theology that was allegedly the guiding motif of the Kairos document and raison d'etre of the School of Theology - as it was known until recently - during the 1980s and early nineties at the University of KwaZulu-Natal, is highly significant. It must be remembered that this paper was first published almost seventeen years ago when the idea of Liberation Theology in the South African context was still strong, though obviously not as strong as it was prior to 1994 when Nelson Mandela was released. Of course one did not have to be particularly prophetic to predict the eclipse of what the Kairos document called 'prophetic theology' since this theology was hardly distinguishable from the agenda of the UDF (United Democratic Front) which was articulating the policies of the then banned ANC. With the

\footnotetext{
18 The extent of the epistemological divide between African and European theology is significantly manifest in Bolaji Idowu's comment on the theology of Tillich and Bonhoeffer. Idowu talks about the 'confusion' about God in the minds of these 'enlightened Westerners' who have 'lost their sense of God' (Bediako 1992:271). But if, as I have been arguing, Western theology is apprehended through the lens of the Enlightenment, then such understandings should not be characterised as 'confused' but rather as normative.

19 In terms of the foregoing discussion I define "European" as those institutions that have been strongly influenced by the European Enlightenment, and not those located in Europe. In the South African context they are defined by their liberal heritage as typified in such institutions as the University of Cape Town, Wits University, and the University of KwaZulu-Natal. The other major theological institutions such as Stellenbosch, the University of the Free State, and UNISA I would suggest have a more confessional influence, in these cases historically being that of the Reformed tradition. 
unbanning of the ANC and its move to mainstream politics after the first democratic elections it soon lost its status as a revolutionary movement (even though it still attempts to present itself as one). With such a move the theology of the Kairos document became redundant and the protagonists of such a theology largely co-opted into the politics of the new status quo.

The other emerging theologies mentioned by Maluleke, with the possible exception of Reconstruction theology, have all increased in need and significance, especially those of the African Independent Churches and Pentecostalism. Numerically these two sectors of the church continue to outstrip all other sectors - yet, ironically, they are the two that are the most neglected and side-lined in the modern academy. Their accommodation in the academy represents a major challenge not only because they are increasingly demanding theological education at the highest level but because the oral nature of the theologies that are emerging from the grassroots of their movements still need to be documented and put into dialogue with other theologies. When it comes to Pentecostalism there seems to be significant prejudice against them on the one hand and on the other a rather uncritical belief in them. The former sentiment I think may come out of the belief that Pentecostal theology is dominated by the prosperity motif - though one cannot dismiss the fact that they are also seen as a threat to the mainline churches - and the latter sentiment I have found amongst some contemporary scholars of Pentecostalism who see them as being a significant modernising force in society, especially with respect to the empowerment of women and creation of an entrepreneurial spirit ${ }^{21}$ (Martin D 2002, Maxwell D 2007). A great deal of research has been done on both the AICs as well as the Pentecostals, especially in the social sciences, but more needs to be done theologically and find its way into mainstream theology in the University. Of particular significance for this essay is that a number of scholars argue that the AICs constitute the most 'authentic' form of African Christianity (see for example Maluleke 1997, Anderson 1991, Oosthuizen 1994) and the success of Pentecostalism in Africa has to do with the affinity between Pentecostalism and an African world view (see Kalu 2008, Anderson 2004, Nkurunziza 2013).

Maluleke's identification of an emergent stream of African theology being broadly evangelical/Pentecostal in nature means that such a stream, far more pronounced now than it was even in 1997, becomes an interesting departure point for the discussion around the clash of worldviews in the modern academy that is the main topic of this essay. This is further supported by the fact that the Pentecostal nature of African theology goes beyond those who are members of Pentecostal churches. African theology, by definition, is a theology of the Spirit, whether it be done by Anglicans, Catholics, Lutherans, or Pentecostals. By this I do not only mean that credence is given to the Holy Spirit as the third person in the Trinity, but that the Spirit becomes an epistemological category within the thinking of African Christians. This implies the belief in a spirit world at the centre of which is Christ and the Holy Spirit (as opposed to ancestors and other spirit beings) which essentially means the agency of the Spirit in all aspects of life, including intentionality and reason. All aspects of life therefore become matters of faith, in the existential, rather than the doctrinally orthodox sense of the word. Cartesian dualism, which continues to be the

21 I took part in a major research project of the Centre for Development and Enterprise (CDE) in 2008 investigating the potential for development of social capital through the Pentecostal Churches. Involving high profile sociologists such as Peter Berger and David Martin the study was premised on the belief that Pentecostalism "promotes attitudes, habits, and dispositions that promote independence, entrepreneurship and development" (CDE website www.cde.org.za "Under the Radar" accessed 22/02/14), and involved a multidisciplinary approach to the subject mainly in the Johannesburg area. 
dominant epistemology of the Western academy, simply cannot make sense. The implication of this for the way theology is done in the academy is profound, and demands much more time and space than this essay has. The best I can do here is to flag some issues for further discussion and debate.

- Firstly, there will have to be a critical reappraisal of some of the basic assumptions upon which the epistemology of the modern academy is established, especially with reference to its approach to religious belief.

I am referring here to the above discussion especially concerning the secularist approach to religious questions in the modern academy. The secularisation thesis that religion would become increasingly less significant in society, even in the West, has in any case proven to be false. Those who held to it in the past (e.g. Peter Berger) no longer believe it to be valid (Berger 1999, Deneulin 2009). I have argued elsewhere that we ignore what I have called the "comeback of God(s)" at our peril and the sooner we take cognisance not only of the religious but enchanted nature of the African world view and allow this to inform our theology the better (Balcomb 2010).

- Secondly the culture of enquiry needs to increase its capacity for a more emic approach in theological research and reflection around issues of the African habitus instead of the etic and deconstructive role that it usually takes.

I am arguing here for a more sympathetic engagement with all the phenomena that surround an African world view and African theology. Theology could take a few leaves out of the books of anthropologists who have engaged positively with the phenomena of witchcraft, spirit possession, ritual and ethnicity for many years. Research proposals, for example, on the issue of spirit possession, witchcraft, the gifts of the Spirit, prayer, or exorcism, from a theological perspective should be acceptable in the academy without the necessity of deconstructing or demythologising such phenomena psychologically, sociologically or culturally. Theology needs to have its own integrity in spite of the influences of the academy to attempt to make it conform to its secular criteria.

- Thirdly the social sciences should not take the place of theology but should assist around questions raised "within, between and about the Christian faith, other religious communities, and the pluralist civil society" (Kombo 2013:107). ${ }^{22}$

I have argued above that theology as a discipline should be allowed its own discourse and exercise its own genius rather than be deconstructed in terms of other social science discourses. This, however, does not mean to say that the social sciences do not have a role to play. In many ways the potency and relevance of religion can best be foregrounded by demonstrating its significance in terms of the social sciences. For example, it has been argued convincingly that religious institutions, for example the church, play a very significant role in African societies which do not have other structures of civil society (see, for example, Gifford 1998). Conversely it may happen that such religious institutions or beliefs have a negative effect on society. The etic approach of the social sciences in such cases would be crucial in explicating this.

22 For a critique of the over-use of the social sciences in the secular academy see Balcomb 2001. 
- Fourthly the concept of contextualisation needs to be re-defined to take into consideration issues around Christianity and the African habitus.

Contextualisation in South Africa, at least in my own institution, has been restricted to the socio-political. However, the rapid change of events that moved South Africa from the apartheid to a post-apartheid society has left the School floundering in terms of its relevancy. It might have done better had it realised that there was some truth in the assertion that "Liberation theology opted for the poor at the same time that the poor opted for Pentecostalism" (Miller and Yamamori 2007:215). While there is still need for a theology of liberation from economic and gender inequality I have argued in this essay that a neglected area of research has to do with the African habitus. If, as I have argued, the Christian gospel has been, and still is being, transacted, interpreted, and inculcated on a multiplicity of levels amongst ordinary people in South African society, then it should be one of the major research tasks of Schools of Theology to investigate how this is being done and what the consequences are for the message itself. Much emphasis has been placed on the work of theological scholars but not enough on the work of ordinary people.

- Fifthly the issue of Human Rights should be covered in such a way that is inclusive of a non-secular paradigm, for example some discussion around the notion of Ubuntu as well as the historical role that religion has played in the development of a culture of human rights in the West.

In my work in the ATF it has become apparent that amongst many Evangelical scholars in Africa the notion of Human Rights as it is understood in the West becomes the door through which a secular agenda is introduced. There is thus a profound, and worrying, suspicion of this notion, but it must be understood in the context in which it takes place that is that it is associated with secularism. While it is true to say that historically in the West the idea that religious faith can be antipathetic towards human rights because religion is associated with intolerance, there is another narrative that locates faith at the centre of the struggle for human rights (see, for example, Sugden 2014). And while the notion of Ubuntu has become somewhat hackneyed and cheapened over the past twenty years or so it still may have purchase in the construction of an African perspective on Human Rights.

- Finally much more work needs to be done in the theological dimension of issues around development; the notion of development itself needs to be further interrogated, and Indigenous Knowledge Systems (IKS) need to inform the process. ${ }^{23}$

I have argued elsewhere (see Balcomb 2012) that the Theology and Development programme in the School of Religion at the UKZN, as important as it is, does not have enough theology and needs more emphasis on critiquing the accepted Western development narrative. This programme also offers an ideal forum for discussion around environmental issues and the African habitus. I have also argued elsewhere that the epistemology of Indigenous Knowledge Systems presents an alternative way of being and knowing that locates the human being in the world in an intersubjective and vulnerable way that is the polar opposite to the Western understanding (Balcomb 2014). Such subjugated epistemologies may constitute a rich resource in the search for an African habitus.

23 Indigenous Knowledge has become a major area of interest, especially amongst scholars working in the field of Development Studies. In this context I am especially emphasizing the need to take seriously the world view that informs Indigenous Knowledge, namely the primal world view. For more on this see Balcomb, 2014. 


\section{Conclusion}

I have argued in this essay that theological education in the secular academy can alienate its graduates from their faith, their context, and their people. I have not argued that it always does. But, that it can, should cause us to be concerned about why this is the case. The main reasons for such alienation, I have argued, are to do with influences of the Enlightenment on the secular academy due to the particular intellectual history of the West. African theology, I have argued, has a different history that continues to unfold a different set of interests, values, priorities, and ways of being and thinking. While Western history cannot be wished away it should not be allowed to dictate this African unfolding. At the least an African perspective needs to be a major dialogue partner in the theological enterprise in the South African academy. At most it should be allowed to write an agenda upon which the conversation takes place. Otherwise we will continue to have the untenable situation where the two histories, while profoundly impacting on each other in society, will not be allowed to dialogue with each other in the academy.

\section{BIBLIOGRAPHY}

Achebe, C 1959. Things Fall Apart. Fawcett, New York.

Anderson, A 1991. Moya - the Holy Spirit in an African context. University of South Africa, Pretoria.

Ashforth, A 2005. Witchcraft, Violence, and Democracy in South Africa. University of Chicago Press, Chicago.

Balcomb, A 1998. "From Liberation to Democracy - Theologies of Bread and Being in the New South Africa”. Missionalia, Vol 26, No. 1, April, pp. 54-73.

Balcomb, A 2012. "What Theology? Whose Development? Interrogating Theology and Development in the Secular Academy." Journal of Theology for Southern Africa, No 142, March, pp. 6-20.

Balcomb, A 2001. "Is God in South Africa or are we still clearing our throats?" Journal of Theology for Southern Africa, vol 111, Nov, pp. 57-65.

Balcomb, A 2014. "Indigenous Worldviews and Environmental Footprints: The case of Prometheus vs Hermes", in Knowing Differently - the Challenge of the Indigenous. GN Devy, G Davis, \& KK Chakravarty (eds.). Routledge, New Delhi, pp. 158-167.

Balcomb, A 2014. Journey into the African sun - soundings in search of another way of being in the world. Unisa, Pretoria.

Bediako, G 2013. "The African Theological Fellowship - an Innovative Model for Evangelical Theological Education" in I Phiri and D Werner (eds.). Handbook of Theological Education in Africa. Pietermaritzburg, Cluster Publications, pp. 934-939.

Bediako, K 1992. Theology and Identity - the impact of culture upon Christian thought in the second century and in modern Africa. Regnum, Oxford.

Berger, P 1999. "The Desecularization of the World - a Global Overview" in

The Desecularization of the World: Resurgent Religion in World Politics. P Berger, (ed.) William Eerdmans, Grand Rapids, pp. 1-18. 
Deneulin, S 2009. Religion in Development: Rewriting the Secular Script. Zed Books, London and New York.

Ellis, S and Ter Haar G 2007. "Religion and politics: taking African epistemologies seriously" in Journal of Modern African Studies, 45 (3):385-401.

Elphick, R 2012. The Equality of Believers - Protestant Missionaries and the Racial Politics of South Africa. University of KwaZulu-Natal Press, Pietermaritzburg.

Idowu, EB 1973. African traditional religion: a definition. SCM, London.

Kato, B 1975. Theological Pitfalls in Africa. Evangelical Publishing House, Kisumu.

Kombo, J 2013. "The Past and Presence of Christian Theology in African Universities" in I Phiri \& D Werner (eds.), Handbook of Theological Education in Africa. Cluster Publications, Pietermaritzburg, pp. 100-107.

Maluleke, TS 1997. "Half a Century of African Christian Theologies: Elements of the emerging agenda for the twenty-first century", Journal of Theology for Southern Africa, Nov, pp. 4-23.

Martin, D 2002. Pentecostalism - the World their Parish. Blackwells, Oxford.

Maxwell, D 2007. African gifts of the Spirit: Pentecostalism and the rise of a Zimbabwean transnational religious movement. James Currey, Oxford.

Miller, D \& Yamamori, T 2007. Global Pentecostalism: The new face of Christian Social Engagement. University of California Press, Berkley.

Nkurunziza, C 2013. "Pentecostal Spirituality - a Disregarded Cornerstone for the Contextualization of African Theologies?" Journal of Theology for Southern Africa, March, no 145, pp. 59-75.

Oosthuizen, G 1994. Afro-Christianity at the Grassroots: Its dynamics and strategies. EJ Brill, Leiden.

Sugden, C 2014. "Biblical Resources for understanding Human Rights", in Seeing New Facets of the Diamond - Christianity as a Universal Faith, Essays in Honour of Kwame Bediakio. Regnum Africa, Akropong-Akuapem, pp. 174-187.

Taylor, C 2007. A Secular Age. Harvard University Press, Cambridge Massachusetts. 